Discussion Paper No. 08-021

\title{
IT Training and Employability of Older Workers
}

Katrin Schleife

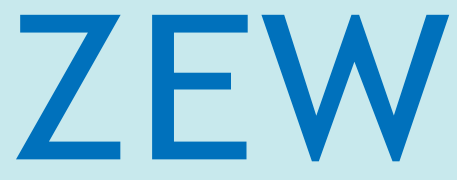

Zentrum für Europäische Wirtschaftsforschung $\mathrm{GmbH}$

Centre for European

Economic Research 
Discussion Paper No. 08-021

\title{
IT Training and Employability of Older Workers
}

\author{
Katrin Schleife
}

Download this ZEW Discussion Paper from our ftp server:

ftp://ftp.zew.de/pub/zew-docs/dp/dp08021.pdf

Die Discussion Papers dienen einer möglichst schnellen Verbreitung von neueren Forschungsarbeiten des ZEW. Die Beiträge liegen in alleiniger Verantwortung der Autoren und stellen nicht notwendigerweise die Meinung des ZEW dar.

Discussion Papers are intended to make results of ZEW research promptly available to other economists in order to encourage discussion and suggestions for revisions. The authors are solely responsible for the contents which do not necessarily represent the opinion of the ZEW. 


\section{Non-technical summary}

This paper focuses on the relationship between firm-provided IT training and the firm's proportion of older workers. In Germany, the relative labor supply of people over fifty is increasing due to the shift in demographics. At the same time, the ongoing technological change is often supposed to be age-biased, thereby leading to a decreasing demand for older workers. Thus, labor supply and labor demand developments with regard to older workers are moving in opposite directions. Providing older workers with IT training could be an appropriate means of increasing their IT skills and thereby enhancing their productivity and employability.

The empirical study is based on data of more than 1,000 firms belonging to the German manufacturing sector and selected services sectors, taken from the ZEW ICT survey of the years 2004 and 2007. The results of the multivariate analyses clearly indicate that a higher IT intensity of firms accompanies a lower proportion of older workers. However, a higher participation rate of older workers in IT training is related to a larger proportion of older workers employed by the firm and alleviates the negative impact of IT intensity.

In order to detect potential differences between IT-intensive and less IT-intensive firms, further analyses are made for two subgroups of the sample. The empirical results show that while a higher IT training participation of older workers is positively related to the proportion of older workers in IT-intensive firms, this relationship is not observable for the less IT-intensive subgroup. Thus, providing older workers with IT training turns out to be particularly important in firms that extensively use IT. These firms generally tend to employ less older workers. 


\section{Zusammenfassung}

Der Schwerpunkt dieses Papiers liegt auf der Untersuchung des Zusammenhangs zwischen der Teilnahmequote älterer Beschäftigter an unternehmensinterner ITWeiterbildung und ihrem Beschäftigungsanteil im Unternehmen. Aufgrund demografischer Veränderungen wächst in Deutschland das relative Arbeitsangebot von über 50-Jährigen. Gleichzeitig führt der rasante technologische Wandel zu einem Rückgang der Arbeitsnachfrage nach Älteren. Somit bewegen sich Arbeitsangebot und Arbeitsnachfrage im Hinblick auf Ältere in entgegengesetzte Richtungen. IT-Weiterbildung für ältere Beschäftigte zielt darauf ab, ihre Produktivität und Beschäftigungsfähigkeit zu erhöhen.

Die für die empirischen Analysen verwendeten Daten von über 1.000 Firmen stammen aus den Wellen 2004 und 2007 der IKT-Umfrage des ZEW, an denen Unternehmen des verarbeitenden Gewerbes und ausgewählter Dienstleistungsbranchen in Deutschland teilgenommen haben. Die Ergebnisse der multivariaten Analysen bestätigen den negativen Zusammenhang zwischen der Intensität der IT-Nutzung in Unternehmen und ihrem Anteil älterer Beschäftigter. Sie zeigen jedoch auch, dass eine höhere Teilnehmerquote älterer Beschäftigter an IT-Weiterbildungsmaßnahmen mit einem höheren Beschäftigungsanteil Älterer einhergeht und den negativen Einfluss der IT-Intensität mildert.

Um herauszufinden, ob hierbei Unterschiede zwischen IT-intensiven und weniger IT-intensiven Unternehmen vorliegen, werden für entsprechende Teilgruppen von Unternehmen zusätzliche Analysen durchgeführt. Die Ergebnisse verdeutlichen, dass ein positiver Zusammenhang zwischen IT-Weiterbildung und Beschäftigungsanteil Älterer nur bei IT-intensiven Unternehmen besteht. Die Teilnahme Älterer an IT-Weiterbildung ist demnach in IT-intensiven Unternehmen von besonderer Bedeutung. Diese Unternehmen weisen im Allgemeinen einen unterdurchschnittlichen Anteil Älterer an ihrer Gesamtbeschäftigung auf. 


\title{
IT Training and Employability of Older Workers*
}

\author{
Katrin Schleife ${ }^{\dagger}$
}

April 2008

\begin{abstract}
This paper empirically analyzes the relationship between firm-provided IT training and the firm's proportion of older workers. Using data from the ZEW ICT survey of the years 2004 and 2007, the results show that a firm's IT intensity plays a crucial role: firms intensively using information technologies employ a significantly smaller proportion of older workers than firms that are less IT-intensive. However, higher participation rates of older workers in IT training are related to a larger proportion of older workers within firms. It turns out that this effect is of particular importance in firms that intensively use IT.
\end{abstract}

Keywords: older workers, IT training, information technologies JEL-Classification: J24, J21, J14

*Acknowledgments: I appreciate helpful comments by Irene Bertschek, Alfred Garloff, Bettina Müller, Jillian Rowe, and Thomas Zwick.

${ }^{\dagger}$ Address: ZEW Mannheim, Centre for European Economic Research, Research Group Information and Communication Technologies, P.O.Box 103443, D-68034 Mannheim, Germany. Email: schleife@zew.de 


\section{Introduction}

In recent years, the German labor market has been strongly influenced by two developments: firstly, as a result of increasing life expectancy, declining fertility rates, and the aging of the baby boom generation, Germany's population is rapidly aging. Induced by the shift in the demographic composition, the younger labor force declines in relative and absolute values while the relative labor supply of people over fifty increases. Secondly, new information and communication technologies (ICT) have become essential in nearly every economic area and have lead to changes in production processes and required skills. An increasing number of employees use a computer at work. The proportion was 46 percent in 2003 and rose to 63 percent by 2006 (Eurostat, 2007). ${ }^{1}$ However, older workers fall behind in using new technologies: data from the ICT survey carried out by the Centre for European Economic Research (ZEW) shows that in firms belonging to the manufacturing sector or to selected services sectors, in 200348 percent of the younger employees aged less than 50 years used a computer at work, but only 34 percent of those aged 50 years or above did.

But what are the reasons that older workers lag behind? Following Bartel and Sicherman (1993), technological change is often supposed to generate or even accelerate skills obsolescence. Older individuals have completed their original training less recently than younger ones. Without further training this results in a lower actual skill level, in particular with regard to IT skills. Moreover, as human capital theory predicts, older workers will participate less in training activities as for them less time remains to amortize the effort. Therefore, older workers often have difficulties in using new technologies and their IT adoption rates are low. These arguments show that the rapid diffusion of new technologies can lead to a decreasing demand for older workers. Technological change is then supposed to be age-biased (Aubert, Caroli, and Roger, 2006). Beckmann (2007) describes how in the course of the ongoing demographic changes the age-biased technological change will become problematic for firms because labor supply and labor demand developments with regard to older workers are moving in opposite directions.

\footnotetext{
${ }^{1}$ These are proportions of computer users in all firms in Germany with 10 or more employees (Eurostat, 2007).
} 
Providing older workers with IT training could be an appropriate means in order to increase their employability. This paper takes a closer look at the relationship between firm-provided IT training for workers aged 50 or above and their proportion in the firm. It thereby sheds some light on an important part of training activities of firms as IT skills have become essential in so many workplaces. Moreover, the extent of IT use within firms is analyzed in more detail by developing an indicator of the firms' IT intensity. This indicator comprises various IT items, such as several IT applications executed by the firm as well as its IT costs. It plays a crucial role in the following analyses as it is closely related to the firms' propensity to provide IT training and its propensity to employ older workers.

Various studies deal with the relationship between IT use and the age structure of the workforce within firms, for example Bartel and Sicherman (1993), Bellmann and Leber (2004), and Beckmann (2007). Other authors study the impact of onthe-job training activities on the individual job stability, for example Büchel and Pannenberg (2004), and Fitzenberger and Prey (1999). However, to my knowledge none of these or further studies specifically concentrate on firm-provided IT training, particularly with regard to older workers, and its relationship with the firms' proportion of older workers. This is the contribution of my paper.

The results of my analyses show that: i) firms with a larger IT intensity employ a smaller proportion of older workers than those firms that are less IT-intensive. ii) Firms with a higher participation rate of older workers in employer-provided IT training employ a larger proportion of older workers three years after the training program, compared to firms with a lower IT training participation of older workers. iii) However, the marginal employment gain of increasing the proportion of trained older workers declines with the rate of IT training participation of older workers. iv) The positive impact of a larger proportion of older workers participating in IT training activities on the firms' proportion of older workers is higher in firms that intensively use IT compared to firms with a lower IT intensity.

The paper proceeds as follows: the next section provides an overview of some theoretical and empirical literature regarding the decision of firms to provide training as well as regarding the impact of job-related training on the job stability of trained workers. Section 3 describes the data used for the analyses. The focus of section 4 is on the derivation of the hypotheses as well as on the description 
of the estimation strategy. Section 5 presents the empirical results and section 6 concludes this paper.

\section{Related Literature}

Generally, firms want to provide training and further qualification if their employees either do not have the appropriate skills or a skill level that is too low, or if they cannot get the human capital they need by hiring new workers. However, following the human capital approach of Becker (1962) where the decision to provide training is made by calculating and comparing the overall costs and benefits of the training investment, firms will invest in firm specific training only. The main reason is that general training could be used in other firms too, and there is a risk that the trained workers will move to another firm. If this happens the firm that provides training cannot get all of the benefits from the training investment, but has to bear all of the costs. That possibility reduces the incentive for a firm to invest in its employees' general skills. The investment for general training has to be borne by the workers themselves.

However, as is stated for example by Stevens (1996) and by Gerlach and Jirjahn (1998) this result holds in perfect labor markets only, where there is full information regarding the skill level of workers and the wages paid by different firms, and where workers can move without restrictions between firms. In general, however, labor markets are not perfect. These imperfections can make general skills specific. For example, certain skills could be useful in many firms, but only a small number of these firms may be located in a certain region (Stevens, 1996). In such a case firms have an incentive to invest in general human capital as the probability that a trained worker stays with the firm is non-zero and firms do not only bear the costs of training but can also expect positive benefits (Stevens, 1996). A positive probability of remaining with the firm arises, for example, from mobility restrictions and from workers' uncertainties regarding the outcome of their prospective labor search process as well as regarding additional transaction costs (Hashimoto, 1981). Moreover, Acemoglu and Pischke (1999) show that the possibility of compressing the wage structure, that is reducing the wages of skilled workers relative to wages of unskilled workers, encourages firms to provide 
general training and to pay for it. The reason is that due to the compressed wage structure, highly qualified workers are paid below their marginal product and therefore bear part of the training costs. Thus, imperfections could indeed lead to firms' investments in general training.

In light of these thoughts, Stevens (1996) defines a supplemental form of training - transferable training - because not all kinds of training can be described by the theoretical tools of general or specific. Transferable training is defined as "training for skills which are of potential value to at least one other firm in addition to the training firm, without any assumption about the nature of the labor market" (Stevens, 1996, p. 26). Purely general and purely specific training then are the extreme cases. If the training a worker receives is transferable but not completely general, the training firm and the worker will share the investment costs. Both have an incentive to bear part of the costs as they expect positive benefits from the training activity. ${ }^{2}$ Thus, the wage profile of the worker rises after the training but remains below his value of the marginal product in his firm (Stevens, 1996). Applying the Coase Theorem, Hashimoto (1981) concludes that the optimal cost share largely depends on the post-training transaction costs that both parties face. However, as Stevens (1996) elaborates, part of the expected economies of training are obtained by an alternative firm as there is the possibility that the worker will move to that firm after the training. This uncertainty at the time the investment decision is made, the so-called poaching externality, may result in under-investment of transferable skills. ${ }^{3}$

The participation in employer-provided training aims at increasing a worker's extent of firm-specific skills, thereby increasing his productivity and employability. The positive effect of training activities on the probability of staying with the firm is demonstrated, for example, by Christensen (2001) using German SOEP data for the years 1984 to 1999. For West German employees the author not only detects a significant reduction in the risk of being laid off after participation in oc-

\footnotetext{
${ }^{2}$ This result can also be assumed for older workers, as the training decision may induce older workers to postpone retirement.

${ }^{3}$ In the limiting cases of general and specific training the externality disappears. Purely specific training has no value to other firms. In the case of completely general training the trained worker gets a wage equal to his marginal product which reduces the expected return to the alternative firm to zero. See Stevens (1996).
} 
cupational training, he also shows that training reduces the individual probability of resigning from a job. A significantly positive impact of job-related training on the stability of individual employment is also discovered by Fitzenberger and Prey (1999), using data from the West German SOEP of the period 1984 to 1997. In addition, they find that the positive effect seems to increase with the duration of the training program. Hübler (1998) also shows positive effects of firm-provided training on the job stability of trained workers for East Germany. He uses eight waves from the specific East German data set "Arbeitsmarkt-Monitor" for the years 1990 to 1994. However, Büchel and Pannenberg (2004) say that for East Germany the empirical findings regarding the relationship between training and employment stability vary between the data sets used and the econometric specifications applied by the different studies.

Several studies find that older workers participate less in training activities than their younger colleagues. Using German data, Büchel and Pannenberg (2004) estimate a significantly lower probability of participating in firm-provided training for workers aged between 45 and 64 years compared to younger workers. According to Larwood, Ruben, Popoff, and Judson (1997) older workers represent a quadruple challenge regarding their retraining activities: firstly, older workers are in greater need of retraining because their original training is less recent compared to their younger colleagues. Secondly, older workers are often believed by their employers to have a lower performance and to be less flexible, less adaptable, and less interested in learning how to handle and work with new technologies. Thirdly, older workers differ in their ability to learn and to use new technologies. Finally, older workers differ in their individual time horizon that remains until retirement, and therefore in the time where the benefits of the training can be achieved. ${ }^{4}$ However, the last of the four points becomes less important if (technological) skills are rapidly depreciating (Bellmann and Leber, 2004). In addition, recent studies find evidence that older workers are not necessarily less but rather differently qualified than younger workers (Clemens, Künemund, and Parey, 2003). Pack et al. (1999) suppose that not age itself makes older workers less productive, but inappropriate working conditions. The use of computers in

\footnotetext{
${ }^{4}$ Actually, Larwood et al. (1997) speak of a triple challenge by pooling together point three and four. However, I think each of both points is important and does not imply the same. They should therefore be examined separately.
} 
the workplace can facilitate work tasks and can therefore help to maintain the physical strength of older workers. ${ }^{5}$ This may reduce older workers' tendency to make use of options to retire early.

As in my analyses, Burgert (2006) focuses on the proportion of older workers in firms when studying the employment effects of on-the-job training. By using German data from the IAB establishment panel, the author was unable to find any evidence of a positive link between the decision of firms to finance training activities and the firms' proportion of older workers. The result remains unchanged for different observation periods and for different forms of training, such as internal or external training courses, attending lectures, performing self-determined learning, and so on. He even finds slightly significantly negative effects in some specifications. However, Burgert (2006) does not consider the number of employees participating in training activities. In addition, as he does not know who is participating, he cannot observe whether older workers receive training. In contrast to his study, my analysis specifically looks at the participation rate of older workers in firm-provided training and estimates its correlation with the proportion of older workers employed by the firm. Moreover it is IT training my study concentrates on.

The impact of IT training on the employment of older workers may depend on the intensity of IT use within the firm. Therefore, a multitude of IT applications as well as other IT-related variables indicating a firm's intensity of IT use will be considered in an indicator which is developed in the next section. Focusing on firms, several authors conclude that the introduction and usage of new technologies is biased against older workers. Empirically analyzing data from the ZEW ICT survey of the year 2002, Bertschek (2004) finds a negative correlation between the firm's proportion of employees predominantly working with a computer and the firm's percentage of older workers. Beckmann (2007) concludes that the technological change in German firms is age-biased as it noticeably leads to a reduction of the relative size of the older workforce, causing a shift in the age-

\footnotetext{
${ }^{5}$ It can be argued that older workers do not need physical strength any longer when working with computers. However, there are workplaces where the computer cannot replace all tasks carried out manually, for example in the field of manufacturing or logistics. Secondly, a decrease of a worker's physical strength is in most cases accompanied by a productivity loss and frequent absence from work due to illness. Thus, employer and employee should aim at maintaining the physical strength of workers even when they work with computers.
} 
structure within firms. His findings are in line with those of Aubert et al. (2006) who analyze French manufacturing firms. Concentrating on firms of the German state of Baden-Württemberg, Boockmann and Zwick (2004) find that the proportion of older workers is smaller in firms with an state-of-the-art technology compared to firms with prior technology. In addition, Wagner (2000) and Pack et al. (1999) state that older workers are often employed in those establishment areas where they produce out-dated and out-phasing product lines. As a result, they are often not involved in the firm's innovation processes. This may also have a negative impact on the proportion of older workers because this kind of age separation reduces older workers' work motivation and increases their incentive to retire early.

\section{Data}

The data used for the empirical analyses stems from two waves of the ZEW ICT survey, a representative business survey carried out by the ZEW in Mannheim. In the years 2004 and 2007 (waves three and four of the survey) around 4,400 firms belonging to the manufacturing sector or to selected services sectors were interviewed. The aim of the survey is to analyze the diffusion of ICT on the level of firms, as well as to study the effects of ICT adoption on employment, productivity, and the success of businesses in Germany.

In addition to the large number of IT questions included in every wave of the ICT survey, the wave of 2004 also includes several questions regarding older workers, that is workers aged 50 years or above. The data generates information on the proportion of older workers employed by the firm (based on the previous year 2003), for example, or the participation of older workers in IT training (in 2003). This provides the possibility of analyzing the factors that affect the employment of older workers in detail.

The following analyses are limited to those firms that participated in the ICT survey in both years, 2004 and 2007. In addition, only firms that provided information about their use of ICT, about the proportion of older workers, and about the participation rate of older workers in within-firm IT training are kept in the 
data set. The net sample used for the empirical analyses then consists of 1,035 firms.

Table 1 provides an overview of the employment of older workers and the participation of workers in IT training within the sample. It shows that in 2006, 90 percent of the firms employ at least one older worker. The firms' proportion of workers who are aged 50 years or above is on average 21 percent in 2006. The value is higher in East Germany (25 percent) than in West Germany (20 percent).

In 29 percent of all firms belonging to the sample older workers participate in IT training activities in the year 2003. The proportion of older workers who receive IT training is 10 percent. If only those firms that provide IT training for older workers are considered, 34 percent of older workers receive IT training on average (not shown in the table).

The proportion of firms that train their younger workers (those who are less than 50 years old) in IT use is 59 percent and is therefore much larger than the proportion of firms providing training for older employees. All in all, the firms train 13 percent of their younger workers in 2003. However, if only those firms that provide IT training for the young are considered, a proportion of 22 percent of younger workers takes part in IT training activities (not shown in the table).

Table 1: Older workers and IT training in firms

\begin{tabular}{lc}
\hline \hline proportion of firms employing older workers in 2006 & .90 \\
East Germany & .91 \\
West Germany & .89 \\
proportion of older workers within firms in 2006 & .21 \\
East Germany & .25 \\
West Germany & .20 \\
proportion of firms providing IT training for older workers in 2003 & .29 \\
participation rate of older workers in IT training in 2003 & .10 \\
proportion of firms providing IT training for younger workers in $\mathbf{2 0 0 3}$ & .59 \\
participation rate of younger workers in IT training in $\mathbf{2 0 0 3}$ & .13 \\
\hline \hline
\end{tabular}

Notes: Sample size: 1,035 firms. Older workers are those aged 50 years or above. Younger workers are those who are less than 50 years old.

Source: Author's calculations based on ZEW ICT survey 2004 and 2007. 
The data suggests that the higher total participation rate of young workers is a result of more firms providing training for them. While nearly 90 percent of the firms employ older workers (88 percent in 2003), less than a third provide training for older workers at all.

One determinant that is expected to influence the proportion of older workers is the extent of IT use within the firm. In the empirical part I use an IT intensity indicator which consists of several IT variables contained in the data set: ${ }^{6}$

- IT applications,

- proportion of employees predominantly working with a computer,

- IT costs,

- open source software for the operating system of computers,

- proportion of computers connected to a network,

- own homepage,

- process innovation.

Before I explain the strategy I use to aggregate these variables, I specify the variables in detail. The first category comprises several IT applications that could be executed by the firm, such as buying and selling products and services via the Internet (e-commerce), performing online marketing, or using customer relationship management software. ${ }^{7}$ The IT application variables are measured by three dummy variables for each application. The first dummy gets the value one if the specific application is 'not used' by the firm, the second dummy represents 'sporadic use', and the third 'wide use'.

\footnotetext{
${ }^{6}$ The IT intensity indicator is created according to Beckmann (2007) who generates an indicator representing technological change. Beckmann (2007) thereby refers to Bresnahan, Brynjolfsson, and Hitt (2002) who construct a workplace organization measure consisting of several variables.

${ }^{7}$ The nine applications taken into account are in detail: selling products and services via the Internet (b2b or b2c e-commerce), buying products and services from suppliers via the Internet, performing online marketing, using an electronic data interchange system, using engineering and controlling software, customer relationship management software, supply chain management software, and performing e-learning.
} 
Secondly, the IT intensity indicator includes a quantitative measure of IT use: the proportion of employees predominantly working with a computer. A larger proportion of computer users indicates a higher IT intensity.

IT-intensive firms are assumed to face higher IT costs because they use state-ofthe-art and advanced hard- and software which often require higher investment $\operatorname{costs}^{8}$ Furthermore these firms need specialized personnel in order to administrate and service their IT equipment. Thus, the IT indicator additionally contains the firms' IT costs per employee including all expenditures related to IT components (hard- and software) and IT specialized staff. As IT expenditures also include costs for IT services that are sourced out, firms are also defined to be ITintensive if they procure a lot of their IT services externally. It is assumed that IT use is nevertheless high within the firm and is supported by the outsourced services. IT costs per employee are grouped into six categories and are included in the IT intensity indicator. ${ }^{9}$

Some of the advanced IT technologies themselves can be considered when generating the IT intensity variable. As, for example, the use of open source software for the operating system of computers requires specific and advanced IT skills, it indicates a greater IT intensity. ${ }^{10}$ The proportion of computers connected to a network as well as whether the firm maintains its own homepage are additionally included in the IT intensity variable. A firm is assumed to be a more advanced IT adopter if it maintains its own homepage and more of its computers are connected to a network. While the latter is measured in percent, maintaining a homepage as well as using open source software are represented by dummy variables taking the value one if this is done by the firm, and the value zero otherwise.

The IT intensity indicator also comprises a dummy variable that is given the value one if the firm underwent some process innovation activities in the year 2003. Process innovations are used in order to restructure business processes and

\footnotetext{
${ }^{8}$ Although IT prices have been declining in previous years on average, advanced technologies are still expensive, especially when they are adopted very early.

${ }^{9}$ The categories of IT costs per employee (in Euro) are: less than 200; 200 to $<555 ; 555$ to $<1,621 ; 1,621$ to $<4,000 ; 4,000$ to $<10,000 ; 10,000$ or more (corresponding to the 10 th, $25 \mathrm{th}, 50 \mathrm{th}, 75 \mathrm{th}$, and $90 \mathrm{th}$ percentile).

${ }^{10}$ In the case of open source software the skill aspect is more important than the cost aspect with regard to IT intensity. Open source software can often be used free of charge.
} 
improve business performance. They are largely based on the use of information technologies. Thus, process innovations indicate a higher IT intensity.

As these aforementioned IT variables are highly correlated, considering them separately as explanatory variables in one estimation could lead to a collinearity bias in the estimation results. Therefore, these variables are pooled in an IT intensity indicator. The indicator variable is generated according to Bresnahan et al. (2002). As the considered IT variables are not equally scaled, each IT variable is standardized in a first step by calculating

$$
\operatorname{STD}\left(x_{k}\right)=\frac{x_{k}-\overline{x_{k}}}{\sigma_{x_{k}}}
$$

where $\overline{x_{k}}$ is the sample mean and $\sigma_{x_{k}}$ the sample standard deviation of the $\mathrm{k}$-th IT variable $x$. The IT intensity indicator is then calculated by adding up the standardized IT variables and standardizing the result once again:

$$
\text { IT intensity }=S T D\left(\sum\left(S T D\left(x_{k}\right)\right)\right. \text {. }
$$

The result is a variable that has zero mean and unity variance. It is independent of the scale level of the original IT variables.

Further variables included in the estimations as controls are described in the following section, where the estimation strategy is explained. An overview of the variables is given in the descriptive Tables 5 and 6 in the appendix.

\section{Hypotheses and Estimation Strategy}

The focus of this paper is on the propensity of firms to employ older workers depending on the amount of firm-provided IT training available to older workers. The analyses regarding that relationship can be described by a two-period model. In period one, firms decide whether to provide IT training for older workers at all, and, if yes, how many workers may participate. From the data of the ZEW 
ICT survey it is not clear whether the participation in IT training is voluntary. ${ }^{11}$ It is assumed here that older workers themselves can choose whether or not to participate in the training activity provided by their employer in period one.

Given the number of older workers participating in IT training in period one, firms decide by period two whether to keep their older workers, to lay off some or all of them, or to employ more older workers. Of course, this decision depends not only on the skill level of the older workers but is also related to many other workerand firm-related factors as well as to the labor market situation. Furthermore, it is not only the firm that determines its own proportion of older workers. It is also older workers employed by the firm in period one that choose whether to stay with the firm. And those older workers who were not employed by the firm in period one can decide by period two whether to apply for a job there. The decision the workers then have to make is related to many individual or firm-related factors and of course also to their labor market situation. But their decision depends not least on the prospect of receiving IT training within the firm. Especially if a firm is IT-intensive one can assume that older workers will have a higher incentive to apply for a job if the firm provides IT training for all or at least for their older employees.

Using data from the ZEW ICT survey of the year 2002, Bertschek (2004) finds a negative correlation between the firm's proportion of workers predominantly using a computer in the workplace and the firm's percentage of older workers. Having an intranet is also negatively correlated with the percentage of older workers. The other IT tasks examined, such as using engineering and controlling software or using databases, have insignificant coefficients. ${ }^{12}$ However, this could be the result of multicollinearity between the IT task variables which increases

\footnotetext{
${ }^{11}$ One might argue that the participation is voluntary if the proportion of older workers participating in IT training is not hundred percent. However, those workers who do not participate in the year of observation could have been forced to participate in that training course the year before. In addition, if the firms know the skill level of their employees they will not provide those older workers with a training for the skills they already have.

${ }^{12}$ The IT variables included in the ZEW ICT survey data vary slightly over the waves. For example in 2002, no questions were asked about the use of open source software. Moreover, in 2002 questions concerning the proportion of trained workers are only asked with regard to all workers, not specifically with regard to older workers.
} 
the variance of the estimators. ${ }^{13}$ In order to take the multicollinearity into account it is econometrically advantageous to develop an IT intensity indicator that comprises several IT tasks as described in the previous section. Given the results of Bertschek (2004) as well as the empirical considerations of Beckmann (2007) and Aubert et al. (2006) regarding the age-biased technological change, my first hypothesis is:

H1: Firms with a larger IT intensity employ a smaller proportion of older workers.

Trained workers are of higher value to the employer and therefore face a lower probability of being laid off. In addition, training participation can increase older workers' motivation to work hard and to postpone retirement. This is especially assumed for IT training as new technologies are extensively used in nearly every economic area today. Older workers trained in IT use have more employment possibilities within the firm and are less likely to become segregated. Moreover, a firm offering IT training for workers of all age groups, not only for the young, becomes attractive for skilled workers of every age group. ${ }^{14}$ All these factors can increase a firm's probability of employing older workers. My second hypothesis therefore is:

H2: Firms with a larger proportion of older workers participating in employerprovided IT training in 2003 exhibit a larger proportion of older workers three years later compared to firms with little or no IT training for older workers.

Larwood et al. (1997) state that although it might readily be agreed that especially those workers with a low skill level need retraining, they do not have the highest probability of participating in training activities. Training requires an effort, and this effort is higher for workers with a lower base level of skills. Thus, the incentive to participate in further training is highest for those who have already obtained a certain skill level. Older workers receiving IT training become familiar with using new technologies and have a higher probability of

\footnotetext{
${ }^{13}$ By estimating additional specifications, each with only one of the IT task variables, Bertschek (2004) indeed finds a negative and significant relationship between the IT task variables and the proportion of older workers.

${ }^{14} \mathrm{~A}$ firm which provides training may of course also become attractive for unskilled workers who are interested in training activities, but these workers are of less interest to the firm.
} 
participating in further IT training. Thus, a higher IT intensity is less harmful for people who participate in training. Therefore, hypothesis three is:

H3: The participation of older workers in firm-provided IT training reduces the negative impact of a firm's IT intensity on the proportion of older workers employed by the firm.

Conceivably, the effect of IT training on the proportion of older workers might differ between IT-intensive firms and less IT-intensive firms, because in IT-intensive firms it is much more important to receive IT skills and to keep these skills upto-date. This provides the fourth hypothesis to be analyzed:

H4: The positive impact of the participation rate of older workers in IT training activities on the proportion of older workers employed by the firm is higher in firms that intensively use IT compared to firms with a lower IT intensity.

Following Bertschek (2004), the determinants of the proportion of older workers employed by the firm are analyzed econometrically by using the fractional response model. This quasi-maximum likelihood estimation method was developed by Papke and Wooldridge (1996) for analyzing fractional response variables bounded between zero and one. Papke and Wooldridge (1996) as well as Wagner (2001) describe the shortcomings of several alternative estimation approaches when analyzing such variables, especially for data where there is the possibility of observing the boundary values. A short overview of that is given in the following in order to motivate the adoption of the fractional response approach for my analyses.

Papke and Wooldridge (1996) analyze employee participation rates in voluntary pension plans in the U.S., Wagner (2001) studies the relationship between firm size and the export/sales ratio in German manufacturing establishments. In both studies, the boundary values of zero and one hundred percent can possibly be observed for the dependent variable. The authors state that since the true model is in general non-linear, estimating a linear model by OLS is inconsistent in the presence of boundary values. Papke and Wooldridge (1996) point out that the linear model could be augmented with non-linear functions of the explanatory variables. However, that modification will not eliminate the risk that the predicted values of the dependent variable lie outside the zero/one interval. 
An alternative to the OLS approach is modelling the log-odds ratio as a linear function, described by $E[\log (Y / 1-Y) \mid X]=X \beta$, where the dependent variable $Y$ varies between zero and one and $X$ describes a vector of explanatory variables. However, a large problem with using log-odds ratios is that if $Y$ takes the value zero or one, the equation is mathematically not well-defined. Thus, adjustments must be made before computing the log-odds ratio, for example by adding an arbitrary small constant to all observations. However, this will arbitrarily change the distribution of the dependent variable (Wagner, 2001).

Another possible solution is the so-called TOBIT approach which is a censored regression model widely used for bounded outcome variables. However, in the literature it is a controversial issue whether this approach is appropriate for a situation where the endogenous variable is bounded to zero as a result of individual choice and not because of non-observability. Maddala (1991) argues that one should not apply the TOBIT model in the former case. On the other hand, Wooldridge (2002) describes the application of the TOBIT approach also in the case of corner solution outcomes, where $Y$ can be zero with positive probability but is a continuous random variable over strictly positive values.

Assuming a particular distribution for $Y$ given $X$ and estimating the parameters of the conditional distribution by maximum likelihood is another possible approach for analyzing a bounded outcome variable (Papke and Wooldridge, 1996). Initially Papke and Wooldridge (1996) suggest the beta distribution where the data is limited to the interval between zero and one. However, this approach also faces limitations as it is a continuous distribution and assumes that the probability of the dependent variable taking a certain value is zero. This means that the extreme values zero and one cannot be justified by the beta distribution. Thus, in data sets where there are many observations of $Y$ with a value of zero or a value of one, this approach is inappropriate.

The data set I use in this paper comprises firms which do not have older workers and firms with a positive proportion of older workers, with a maximum value of one hundred percent. Thus, the outcome variable is a fractional response variable, defined on a closed interval $[0,1]$. Given the shortcomings of the alternative models described above, I use the quasi-maximum likelihood estimation procedure (QMLE) of Papke and Wooldridge (1996), the so-called fractional response model, for my analyses. Papke and Wooldridge (1996) use a non-linear function 
$G($.$) for estimating the expected values of the dependent variable y_{i}$ conditional on a vector of covariates $x_{i}$. The model can be written as

$$
E\left(y_{i} \mid x_{i}\right)=G\left(x_{i} \beta\right)
$$

where in my case $y_{i}$ is the proportion of older workers employed by the firm $i$ in 2006. The chosen $G($.$) is a cumulative distribution function satisfying$ $0<G()<$.1 . This ensures that the predicted values of $y_{i}$ lie in the interval between zero and one.

Following Papke and Wooldridge (1996) the multinomial logistic function

$$
E\left(y_{i} \mid x_{i}\right)=\frac{e^{x_{i} \beta}}{1+e^{x_{i} \beta}}
$$

is applied for $G($.$) . As suggested by the authors I assume a Bernoulli distribution$ for $y_{i}$ and maximize the following binary choice log-likelihood function using QMLE:

$$
l_{i}(\beta)=y_{i} \log \left[G\left(x_{i} \beta\right)\right]+\left(1-y_{i}\right) \log \left[1-G\left(x_{i} \beta\right)\right]
$$

Papke and Wooldridge (1996) show that the obtained quasi-maximum likelihood estimator, $\hat{\beta}$, is consistent and $\sqrt{N}$-asymptotically normal distributed regardless of the distribution of $y_{i}$ conditional on $x_{i}$.

The parameter vector $\beta$ measures the impact of the considered covariates $x_{i}$ on the proportion of older workers. While the dependent variable stems from the ICT survey wave 2007, the covariates come from the data set of 2004 . The most important covariates in my analyses are the firm's IT intensity and the proportion of older workers who receive IT training within the firm. The composition of the IT intensity variable is explained in detail in the previous section. The participation rate of older workers in IT training is measured in percent (and divided by 100).

Further determinants considered in the estimations are size, age, and industry of the firm, the existence of a works council, the firm's expectations regarding 
the development of turnover between 2003 and 2004, the proportion of employees with a university degree, the proportion of employees working part-time, and the region (East or West Germany). The firm size is measured by five categories of the number of employees in 2003. The age of the firm is considered as a dummy variable having the value one if the firm is less than seven years old and having the value zero if the firm age is seven years or more. This threshold is chosen in order to differentiate between young and old firms. As done by Bertschek (2004), I make the assumption that firms having survived for seven years can be regarded as established. Long-established firms should be shown to have larger proportions of older workers, as start-up firms probably tend to employ younger workers rather than older ones (Boockmann and Zwick, 2004).

The existence of a works council is presented by a dummy variable that has the value one if the firm has a works council and the value zero otherwise. Works councils can help to impose restrictions on employers to lay off older workers (and substitute them with younger workers, for example). In addition, they can improve working conditions by requesting training activities. They have the right to influence the decision on the kind of training that is provided by the employer and on the recipients of training, especially if there is a risk that specific groups of workers, for example the older ones, are excluded from those activities (Bellmann and Ellguth, 2006). The dismissal restrictions and the improved training possibilities can be assumed to improve the work motivation of older employees and to provide incentives to postpone retirement. The empirical results of Bertschek (2004) and Boockmann and Zwick (2004) show that having a works council is positively associated with a firm's proportion of older workers.

The expectation regarding the turnover development between 2003 and 2004 is measured by three dummy variables. The first takes the value one if a decline in turnover is expected. The second becomes one if the turnover is expected to remain unchanged. And the third dummy variable takes the value one if the employer expects an increase in turnover. As it can be assumed that in economically difficult times firms try to save costs and do not have the financial means to hire young workers, pessimistic prospects regarding turnover development are expected to be positively correlated with the proportion of older workers. The industry the firm belongs to is measured by 14 industry dummies. 
To complete this section, some remarks address the problem of endogeneity. According to Zwick (2005), an 'unobserved heterogeneity bias' can occur if firms which provide IT training for their older workers structurally differ from those that do not provide it, due to firm-specific unobserved factors such as the firm's management quality, the activity of the personnel department, or the motivation of the workforce. Zwick (2005) uses panel estimation techniques to correct for this kind of endogeneity problem. A 'selectivity bias' could be the result of random transitory shocks that affect the proportion of older workers employed by the firm and the decision of employers to provide IT training (Zwick, 2005). Such external shocks can be, for example, a deterioration of market conditions, changes in retirement regulations, or the introduction of unspecific subsidies for employers with regard to older workers. In general, an instrumental variables approach is applied in order to deal with this problem of selectivity. In addition, the possibility of 'reversed causality' has to be kept in mind.

Part of the endogeneity problem is taken into account in my analyses by measuring the employment effect of IT training after three years. In addition to this time lag, the assumption that a worker's decision to participate in IT training is voluntary helps to identify the causal effect. However, some endogeneity issues remain. Thus, the estimated parameters should be cautiously interpreted.

\section{Empirical Results}

\subsection{Determinants of IT Training}

Before empirically analyzing the differences in the proportion of older workers I provide some insight into what factors drive a firm's probability of offering IT training. It is assumed that the IT skills aquired by participating in firmprovided IT training are transferable, as defined by Stevens (1996). This gives older workers the possibility of using their IT skills when they move to another employer. However, at least part of the training costs would be borne by the firm if it decides to invest in training. Several firm characteristics affect the (potential) training costs of firms and therefore their decision whether to invest in training or not. 
Using the ZEW ICT survey 2004, a firm's probability of providing IT training is measured by a binary variable that has the value one if a firm provides IT training to its employees and zero otherwise. I use a PROBIT model to estimate the coefficients. The resulting marginal effects from the PROBIT estimations are presented in Table 2. Besides the factors considered in specification (1), such as firm size, firm age, and proportion of highly qualified employees, specification (2) additionally includes the IT intensity indicator.

The results largely support the expectations. They show that the size of the firm is highly correlated with the probability of providing IT training. Larger firms are significantly more likely to offer IT training compared to small firms with less than ten employees. One reason could be that larger firms are more likely to benefit from economies of scale. In addition, they often provide internal labor markets which make it useful to evaluate and adapt the skill level of the employees in order to find the optimal match of workers and positions within the firm (Gerlach and Jirjahn, 1998).

Firms in the 'banks and insurances', 'electronic processing/telecommunication', 'technical services', 'electrical engineering', and 'precision instruments' industries are significantly and positively related to IT training compared to firms of the 'metal and machine construction' industry. They can be assumed to be ITintensive industries where IT training is particularly needed.

Looking at specification (1), the proportion of employees with a university degree turns out to be significantly and positively correlated with a firm's decision to provide IT training. However, the relation becomes insignificant once IT intensity is examined (specification (2)). Education and IT use are often found to have a highly positive correlation.

As expected, IT intensity turns out to be a driving force regarding a firm's probability of providing IT training (specification (2)). However, the firm size as well as the above-mentioned industries show again significant coefficients. The correlation of these variables with the probability of providing IT training cannot be explained by IT intensity. 
Table 2: Determinants of providing IT training in 2003

\begin{tabular}{|c|c|c|}
\hline \multicolumn{3}{|c|}{ dependent variable: probability of providing IT training } \\
\hline variable (reference group) & (1) & $(2)$ \\
\hline \multicolumn{3}{|l|}{ firm size (ref.: less than 10 employees) } \\
\hline $10-49$ & $.225(.027)^{* * *}$ & $.189(.028)^{* * *}$ \\
\hline $50-249$ & $.408(.028)^{* * *}$ & $.356(.033)^{* * *}$ \\
\hline $250-499$ & $.395(.020)^{* * *}$ & $.370(.026)^{* * *}$ \\
\hline 500 or more & $.417(.016)^{* * *}$ & $.400(.020)^{* * *}$ \\
\hline firm age $<7$ years (ref: 7 or more years) & $-.041(.042)$ & $-.063(.041)$ \\
\hline proportion of employees with a university degree & $.215(.064)^{* * *}$ & $.054(.064)$ \\
\hline proportion of part-time employees & $-.001(.091)$ & $.016(.089)$ \\
\hline \multicolumn{3}{|l|}{ expected turnover development ${ }^{i}$ (ref.: increase) } \\
\hline reduction & $-.029(.036)$ & $-.000(.035)$ \\
\hline unchanged & $-.059(.030)^{*}$ & $-.031(.029)$ \\
\hline east & $-.030(.031)$ & $.014(.030)$ \\
\hline works council & $.020(.040)$ & $.000(.038)$ \\
\hline \multicolumn{3}{|l|}{ industry (ref.: metal and machine construction) } \\
\hline consumer goods & $.014(.056)$ & $-.008(.056)$ \\
\hline chemical industry & $.047(.064)$ & $.020(.067)$ \\
\hline other raw materials & $-.014(.059)$ & $-.024(.057)$ \\
\hline electrical engineering & $.132(.059)^{* *}$ & $.104(.060)^{*}$ \\
\hline precision instruments & $.107(.050)^{* *}$ & $.085(.050)^{*}$ \\
\hline automobile manufacturing & $.009(.067)$ & $.018(.062)$ \\
\hline wholesale trade & $-.028(.069)$ & $-.084(.068)$ \\
\hline retail trade & $.041(.057)$ & $.015(.059)$ \\
\hline transportation and postal services & $.064(.059)$ & $.061(.059)$ \\
\hline banks and insurances & $.242(.047)^{* * *}$ & $.172(.054)^{* * *}$ \\
\hline electronic processing/telecommunication & $.263(.044)^{* * *}$ & $.131(.060)^{* *}$ \\
\hline technical services & $.176(.052)^{* * *}$ & $.124(.055)^{* *}$ \\
\hline other business-related services & $.085(.056)$ & $.035(.056)$ \\
\hline IT intensity ${ }^{i i}$ & & $.124(.015)^{* * *}$ \\
\hline pseudo- $\mathbf{R}^{2}$ & .213 & .257 \\
\hline number of observations & 1,035 & 1,035 \\
\hline
\end{tabular}

Notes: Probit estimation. The table shows the average marginal effects. Robust standard errors in parentheses. $* * *, * *, *$ indicate significance at the $1 \%, 5 \%$ and $10 \%$ level.

$\left.{ }^{i}\right)$ Expectation concerning the development of turnover in 2004 compared to 2003.

${ }^{i i}$ ) IT intensity is an indicator comprising several IT variables. See section 3 for details. Source: Author's calculations based on ZEW ICT survey 2004. 


\subsection{IT Training and Employment of Older Workers}

The hypotheses developed in section 4 are econometrically analyzed in this section. The fractional response model is applied and the results are shown in Table 3 .

In accordance with hypothesis $\mathrm{H} 1$ the results clearly indicate a negative relationship between a firm's IT intensity and its proportion of older workers. This result holds while controlling for many other firm-related characteristics, such as firm size, firm age, or industry. As discussed before, these findings are in line with those of Beckmann (2007) and Bertschek (2004).

Providing older workers with IT training could be an appropriate means to reduce the negative impact of a high IT intensity because older workers can get to know how to use these new technolologies, and can become more productive. Indeed, the results of specification (2) and (3), where IT training variables are considered, show a positive effect of older workers' IT training on the propensity of firms to employ older workers, thereby supporting hypothesis H2. However, as the quadratic term of IT training shows a significantly negative coefficient, the positive correlation between older workers' participation in IT training and the proportion of older workers declines with the rate of IT training participation of older workers. One possible explanation is that firms tend to train those workers first for which the highest productivity gain is expected. The marginal increase in productivity therefore declines with the proportion of trained older workers. Thus, a higher participation rate of older workers in IT training enhances the propensity of firms to employ older workers. But the employment gain of increasing the IT training participation rate by a small unit is higher in firms with a relatively small proportion of trained older workers compared to firms with a large proportion. Considering older workers' IT training in specification (2) increases the absolute value of the IT intensity coefficient. Thus, in line with hypothesis H3, IT training helps to alleviate the negative effect of IT intensity. 
Table 3: Determinants of a firm's proportion of older workers in 2006

\begin{tabular}{|c|c|c|c|}
\hline \multicolumn{4}{|c|}{ dependent variable: proportion of older workers within a firm } \\
\hline variable (reference group) & (1) & $(2)$ & (3) \\
\hline \multicolumn{4}{|l|}{ firm size (ref.: less than 10 employees) } \\
\hline $10-49$ & $-.134(.100)$ & $-.151(.099)$ & $-.152(.100)$ \\
\hline $50-249$ & $-.303(.119)^{* *}$ & $-.352(.119)^{* * *}$ & $-.351(.119)^{* * *}$ \\
\hline $250-499$ & $-.330(.176)^{*}$ & $-.398(.177)^{* *}$ & $-.390(.177)^{* *}$ \\
\hline 500 or more & $-.222(.162)$ & $-.306(.162)^{*}$ & $-.302(.162)^{*}$ \\
\hline firm age $<7$ years (ref: 7 or more years) & $-.162(.105)$ & $-.160(.104)$ & $-.164(.104)$ \\
\hline proportion of employees with a university degree & $-.085(.208)$ & $-.117(.208)$ & $-.120(.207)$ \\
\hline proportion of part-time employees & $.616(.214)^{* * *}$ & $.619(.212)^{* * *}$ & $.620(.212)^{* * *}$ \\
\hline \multicolumn{4}{|l|}{ expected turnover development $^{i}$ (ref.: increase) } \\
\hline reduction & $.220(.085)^{* * *}$ & $.224(.085)^{* * *}$ & $.224(.085)^{* * *}$ \\
\hline unchanged & $.059(.074)$ & $.066(.074)$ & $.066(.074)$ \\
\hline east & $.309(.077)^{* * *}$ & $.296(.077)^{* * *}$ & $.297(.077)^{* * *}$ \\
\hline works council & $.377(.089)^{* * *}$ & $.369(.088)^{* * *}$ & $.366(.088)^{* * *}$ \\
\hline \multicolumn{4}{|l|}{ industry (ref.: metal and machine construction) } \\
\hline consumer goods & $-.262(.145)^{*}$ & $-.271(.144)^{*}$ & $-.277(.144)^{*}$ \\
\hline chemical industry & $-.161(.167)$ & $-.171(.167)$ & $-.169(.167)$ \\
\hline other raw materials & $-.018(.128)$ & $-.029(.128)$ & $-.027(.129)$ \\
\hline electrical engineering & $-.016(.152)$ & $-.040(.151)$ & $-.038(.151)$ \\
\hline precision instruments & $-.273(.124)^{* *}$ & $-.281(.124)^{* *}$ & $-.283(.125)^{* *}$ \\
\hline automobile manufacturing & $-.441(.170)^{* * *}$ & $-.443(.171)^{* * *}$ & $-.445(.170)^{* * *}$ \\
\hline wholesale trade & $-.172(.146)$ & $-.199(.148)$ & $-.199(.148)$ \\
\hline retail trade & $-.218(.153)$ & $-.241(.152)$ & $-.247(.152)$ \\
\hline transportation and postal services & $.320(.138)^{* *}$ & $.302(.138)^{* *}$ & $.296(.138)^{* *}$ \\
\hline banks and insurances & $-.212(.179)$ & $-.256(.182)$ & $-.262(.182)$ \\
\hline electronic processing/telecommunication & $-.209(.187)$ & $-.227(.185)$ & $-.247(.185)$ \\
\hline technical services & $-.125(.181)$ & $-.135(.178)$ & $-.137(.178)$ \\
\hline other business-related services & $-.110(.161)$ & $-.105(.161)$ & $-.108(.160)$ \\
\hline IT intensity ${ }^{i i}$ & $-.212(.041)^{* * *}$ & $-.226(.041)^{* * *}$ & $-.235(.043)^{* * *}$ \\
\hline prop. of older workers participating in IT training & & $1.647(.405)^{* * *}$ & $1.651(.402)^{* * *}$ \\
\hline (prop. of older w. participating in IT training) ${ }^{2}$ & & $-1.669(.463)^{* * *}$ & $-1.794(.488)^{* * *}$ \\
\hline (IT intensity) $\mathrm{x}$ (prop. of older $\mathrm{w}$. with IT training) & & & $.170(.147)$ \\
\hline constant & $-1.365(.135)^{* * *}$ & $-1.372(.134)^{* * *}$ & $-1.371(.135)^{* * *}$ \\
\hline log pseudolikelihood & -382.742 & -381.728 & -381.650 \\
\hline number of observations & 1,035 & 1,035 & 1,035 \\
\hline
\end{tabular}

Notes: Fractional response model. Robust standard errors in parentheses.

$* * *, * *, *$ indicate significance at the $1 \%, 5 \%$ and $10 \%$ level.

$\left.{ }^{i}\right)$ Expectation concerning the development of turnover in 2004 compared to 2003.

$\left.{ }^{i i}\right)$ IT intensity is an indicator comprising several IT variables. See section 3 for details.

Source: Author's calculations based on ZEW ICT survey 2004 and 2007. 
Looking at the other control variables, the estimation results show that compared to firms with less than ten employees a higher firm size is accompanied by a significantly smaller proportion of older workers. A negative relationship between the size of the firm and the proportion of older workers is also described by Bertschek (2004). The results also show that firms which have a works council exhibit a larger proportion of older workers. This result is in line with the expectations. As described above, a works council is likely to improve the working conditions of older employees.

Firms expecting a reduction in turnover compared to the previous year employ a larger proportion of older workers three years later than firms expecting a rise in turnover. This can be explained by cost-saving arguments as provided above. In addition, in his study regarding West Germany, Beckmann (2001) finds that firms that are forced to reduce staff tend to lay off younger workers rather than their older colleagues. This could be the result of higher protection from dismissal of older workers, for example. Moreover, Beckmann (2001) states that the exchange of information could be another reason. Younger workers observe the unreliable behavior of the firm with regard to its older workers and may expect the same for themselves in the future. Possible consequences are a lack of motivation, a decreasing willingness to undergo training, and a higher fluctuation of employees (ibid.). In addition, the wage costs of the firm could increase if new workers call for higher wages as a kind of risk compensation (ibid.). Beckmann concludes that the anticipated damage to the firm's reputation may therefore lead to a higher incidence of laying off younger workers instead of older ones. This leads to a larger proportion of older workers if the staff is reduced as a consequence of expecting a decline in turnover.

A larger proportion of part-time workers accompanies a larger proportion of older workers. According to Beckmann (2001), this could be due to internal strategies of making working hours more flexible and thereby avoiding staff reduction. Regarding differences between East and West Germany, several studies show that in the eastern part the firms' proportion of older workers is significantly larger. This positive relationship can also be found in the results provided here. Moreover, consistent with the findings of Bertschek (2004), the effect of the firm age dummy is not significantly different from zero. It therefore makes no difference to the 
proportion of older workers whether the firm has existed for less than seven years or is already long-established.

The results of further specifications that include the participation rate of all workers in IT training show that it is not significantly related to the proportion of older workers (not shown in the table). This provides evidence that it is not IT training for all workers that is important for a firm's employment of older workers; instead, the crucial factor is the firm's supply of IT training for older workers in particular.

Specification (3) shown in Table 3 additionally includes an interaction term of IT intensity and the proportion of older workers receiving IT training. It captures whether the effect of older workers' IT training on the proportion of older workers is different for increasing values of IT intensity. The coefficient of the interaction term is positive but not significantly different from zero. To enhance the analysis of the differences between IT-intensive and less IT-intensive firms, however, I estimate the coefficients for two subsamples. The first group includes those firms intensively using IT with a value of IT intensity above zero (that is, above the mean). The second group consists of firms with a relatively low IT intensity (values less than or equal to zero). ${ }^{15} 552$ firms belong to the first subgroup, 483 to the second. The two subgroups are described in Tables 7 to 9 in the appendix. Among other things, the tables confirm that the mean proportion of older workers is lower in the IT-intensive subgroup (17 percent versus 25 percent). ${ }^{16}$

The estimation results for the two subgroups are provided in Table 4. The fractional response model is again applied. The results show that the IT intensity is significantly negatively correlated with the proportion of older workers only for IT-intensive firms. In addition, there are differences between the two subsamples regarding the correlations between older workers' IT training participation and the proportion of older workers. Within the group of IT-intensive firms, providing IT training for older workers in 2003 is crucial as it is associated with a significantly larger proportion of older workers in 2006. Again, the quadratic term of IT training for older workers has a significantly negative coefficient. Thus, the

\footnotetext{
${ }^{15}$ The values of the IT intensity variable range between -2.74 and 3.01 with a mean of zero; see Table 6 in the appendix as well as the description of the variable in section 3 .

${ }^{16}$ The $t$-test on the equality of means shows that the difference is significant.
} 
employment gain from increasing the trained proportion of older workers by one unit declines with the training intensity.

Contrary to the IT-intensive subgroup the IT training intensity of older workers does not have a significant influence on the proportion of older workers for those firms that use IT less intensively. This result supports hypothesis H4 stating that the positive impact of IT training participation of older workers on the firm's proportion of older workers is higher in firms that intensively use IT compared to firms with a lower IT intensity. Although firms of the less IT-intensive subgroup employ larger proportions of older workers few of them provide them with IT training. In the data set there are only 76 in 483 (16 percent) less IT-intensive firms that arrange IT training for their older workers. ${ }^{17}$

Within both subgroups firms with a works council as well as firms that are located in East Germany exhibit a significantly larger proportion of older workers. While for the less IT-intensive firms the proportion of part-time employees is another significantly positive factor, this relation cannot be found for the IT-intensive firms. For the latter however, firm size and firm age are further important factors. This cannot be observed in the less IT-intensive subgroup.

When applying the logistic function to be the link function of the dependent variable within the fractional response model, it is assumed that this is the correct distribution function. In addition, it is assumed that all relevant variables are considered on the right hand side of the equation, and no variables are included that should not be in the model. I use Tukey's one-degree-of-freedom test for non-additivity, also known as link test, to find out whether these assumptions apply to my model (Tukey, 1949). Since the test turns out to be not significant for specification (2) and (3) shown in Table 3, I cannot reject the null hypothesis that the model is specified correctly.

\footnotetext{
${ }^{17}$ The proportion of IT-intensive firms that provide their older workers with IT training is 40 percent.
} 
Table 4: Determinants of a firm's proportion of older workers in 2006

\section{- IT-intensive versus less IT-intensive firms}

\begin{tabular}{|c|c|c|}
\hline \multicolumn{3}{|c|}{ dependent variable: proportion of older workers within firms } \\
\hline variable (reference group) & $\begin{array}{l}\text { IT-intensive } \\
\quad \text { firms }^{i i}\end{array}$ & $\begin{array}{l}\text { less IT-intensive } \\
\quad \text { firms }^{i i}\end{array}$ \\
\hline \multicolumn{3}{|l|}{ firm size (ref.: less than 10 employees) } \\
\hline $10-49$ & $-.273(.157)^{*}$ & $-.101(.126)$ \\
\hline $50-249$ & $-.583(.172)^{* * *}$ & $-.242(.172)$ \\
\hline 250-499 & $-.460(.220)^{* *}$ & $-.516(.328)$ \\
\hline 500 or more & $-.397(.213)^{*}$ & $-.417(.249)^{*}$ \\
\hline firm age $<7$ years (ref: 7 or more years) & $-.387(.130)^{* * *}$ & $-.034(.153)$ \\
\hline proportion of employees with a university degree & $-.371(.229)$ & $.462(.354)$ \\
\hline proportion of part-time employees & $.227(.366)$ & $.897(.276)^{* * *}$ \\
\hline \multicolumn{3}{|l|}{ expected turnover development ${ }^{i}$ (ref.: increase) } \\
\hline reduction & $.277(.111)^{* *}$ & $.208(.126)^{*}$ \\
\hline unchanged & $.107(.094)$ & $.008(.111)$ \\
\hline east & $.252(.111)^{* *}$ & $.293(.107)^{* * *}$ \\
\hline works council & $.342(.108)^{* * *}$ & $.342(.140)^{* *}$ \\
\hline \multicolumn{3}{|l|}{ industry (ref.: metal and machine construction) } \\
\hline consumer goods & $-.092(.198)$ & $-.311(.197)$ \\
\hline chemical industry & $-.086(.257)$ & $-.257(.215)$ \\
\hline other raw materials & $-.094(.191)$ & $-.045(.164)$ \\
\hline electrical engineering & $-.184(.206)$ & $.047(.201)$ \\
\hline precision instruments & $-.229(.192)$ & $-.354(.151)^{* *}$ \\
\hline automobile manufacturing & $-.297(.218)$ & $-.542(.241)^{* *}$ \\
\hline wholesale trade & $-.166(.216)$ & $-.281(.210)$ \\
\hline retail trade & $-.074(.235)$ & $-.293(.192)$ \\
\hline transportation and postal services & $.037(.207)$ & $.480(.173)^{* * *}$ \\
\hline banks and insurances & $-.148(.205)$ & $-.552(.426)$ \\
\hline electronic processing/telecommunication & $-.044(.215)$ & $-.840(.303)^{* * *}$ \\
\hline technical services & $.124(.203)$ & $-.707(.319)^{* *}$ \\
\hline other business-related services & $-.283(.231)$ & $.098(.202)$ \\
\hline IT intensity ${ }^{i i}$ & $-.332(.098)^{* * *}$ & $-.059(.083)$ \\
\hline prop. of older workers participating in IT training & $2.427(.473)^{* * *}$ & $.381(.777)$ \\
\hline (prop. of older workers participating in IT train.) ${ }^{2}$ & $-2.397(.511)^{* * *}$ & $-.467(1.046)$ \\
\hline constant & $-1.178(.218)^{* * *}$ & $-1.271(.182)^{* * *}$ \\
\hline log pseudolikelihood & -183.316 & -194.916 \\
\hline number of observations & 552 & 483 \\
\hline
\end{tabular}

Notes: Fractional response model. Robust standard errors in parentheses.

$* * *, * *, *$ indicate significance at the $1 \%, 5 \%$ and $10 \%$ level.

$\left.{ }^{i}\right)$ Expectation concerning the development of turnover in 2004 compared to 2003.

${ }^{i i}$ ) IT intensity is an indicator comprising several IT variables. IT-intensive firms are those firms with IT intensity greater than zero, less IT-intensive firms have an IT intensity of less than or equal to zero. See section 3 for details.

Source: Author's calculations based on ZEW ICT survey 2004 and 2007. 


\section{Concluding Remarks}

This paper focuses on the relationship between firm-provided IT training and the firm's proportion of older workers. In Germany, the relative labor supply of older workers is increasing due to the shift in demographics. At the same time, the ongoing technological change is often supposed to be age-biased, thereby leading to a decreasing demand for older workers. Thus, labor supply and labor demand developments are moving in opposite directions. Providing older workers with IT training could be an appropriate means of reducing the negative impact of an extensive use of new information technologies in the workplace.

My empirical analyses are based on firm data from the ZEW ICT survey of the years 2004 and 2007. Applying the fractional response model, the estimation results clearly indicate that a higher IT intensity of firms accompanies a lower proportion of older workers. However, a higher participation rate of older workers in IT training is related to a larger proportion of older workers employed by the firm and alleviates the negative impact of IT intensity.

Further analyses of two subgroups of the sample show that while a higher IT training participation of older workers is positively related to the proportion of older workers in IT-intensive firms, this relationship is not observable for the less IT-intensive subgroup. Thus, providing older workers with IT training turns out to be particularly important in firms that extensively use IT.

Some final notes concern a few shortcomings of the data set used as well as some ideas for future research. Unfortunately, the data of the ZEW ICT survey does not provide more detailed information about the IT training activities. It does not indicate, for example, whether there are training courses specifically provided for older employees. Information about the content as well as the level of training would be useful. There may be a high training participation rate of older workers, but these workers are only given basic IT training, while the younger participants receive advanced IT courses. In addition, the frequency and the duration of the training program are not addressed in the survey. Such data could help to identify causal effects.

Future research should comprise in-depth analyses of endogeneity questions, such as 'unobserved firm-related heterogeneity' and 'selectivity bias'. Part of the en- 
dogeneity problem is taken into account in my analyses due to the temporal structure of the data used. However, some endogeneity issues remain. Using panel data or linked employer-employee data could help to mitigate possible distortions. 


\section{Appendix}

Table 5: Firm characteristics I

\begin{tabular}{|c|c|c|}
\hline & proportion $^{i}$ & $\mathbf{N}$ \\
\hline \multicolumn{3}{|l|}{ firm size (in groups) } \\
\hline less than 10 employees & .21 & 221 \\
\hline $10-49$ & .39 & 404 \\
\hline $50-249$ & .29 & 295 \\
\hline $250-499$ & .05 & 56 \\
\hline 500 or more employees & .06 & 59 \\
\hline firm age less than 7 years & .11 & 118 \\
\hline \multicolumn{3}{|l|}{ industry } \\
\hline consumer goods & .08 & 81 \\
\hline chemical industry & .05 & 56 \\
\hline other raw materials & .07 & 70 \\
\hline metal and machine construction & .12 & 123 \\
\hline electrical engineering & .06 & 66 \\
\hline precision instruments & .09 & 88 \\
\hline automobile manufacturing & .05 & 51 \\
\hline wholesale trade & .05 & 48 \\
\hline retail trade & .08 & 85 \\
\hline transportation and postal services & .07 & 73 \\
\hline banks and insurances & .05 & 53 \\
\hline electronic processing/telecommunication & .07 & 75 \\
\hline technical services & .08 & 86 \\
\hline other business-related services & .08 & 80 \\
\hline \multicolumn{3}{|l|}{ region } \\
\hline east & .24 & 244 \\
\hline west & .76 & 791 \\
\hline \multicolumn{3}{|l|}{ expected development of turnover ${ }^{i i}$} \\
\hline decline & .22 & 226 \\
\hline constant & .40 & 416 \\
\hline increase & .38 & 393 \\
\hline works council exists & .32 & 334 \\
\hline firm provides training & .81 & 837 \\
\hline firm provides IT training & .61 & 636 \\
\hline firm provides IT training for older workers & .29 & 296 \\
\hline
\end{tabular}

Notes: Characteristics of firms included in the sample for analyzing the proportion (prop.) of older workers. $\mathrm{N}=1,035$.

$\left.{ }^{i}\right)$ Percentage in sample.

$\left.{ }^{i i}\right)$ Expectation concerning the development of turnover in 2004 compared to 2003.

Source: Author's calculations based on ZEW ICT survey 2004. 
Table 6: Firm characteristics II

\begin{tabular}{|c|c|c|c|c|c|}
\hline & Mean & Std. Dev. & Min & $\operatorname{Max}$ & $\mathbf{N}$ \\
\hline firm size & 128.61 & 408.53 & 1 & 8,000 & 1,035 \\
\hline prop. of older workers in 2006 & .21 & .17 & 0 & 1 & 1,035 \\
\hline prop. of workers with a university degree & .22 & .26 & 0 & 1 & 1,035 \\
\hline prop. of part-time workers & .12 & .16 & 0 & 1 & 1,035 \\
\hline prop. of workers using a computer ${ }^{i}$ & .48 & .34 & 0 & 1 & 1,035 \\
\hline prop. of workers receiving IT training & .13 & .21 & 0 & 1 & 1,035 \\
\hline prop. of older workers receiving IT training & .10 & .23 & 0 & 1 & 1,035 \\
\hline prop. of younger workers receiving IT training & .13 & .22 & 0 & 1 & 1,035 \\
\hline IT intensity ${ }^{i i}$ & .00 & 1.00 & -2.74 & 3.01 & 1,035 \\
\hline
\end{tabular}

Notes: Characteristics of firms included in the sample for analyzing the proportion (prop.) of older workers. All variables are taken from the wave of 2004, except the proportion of older workers in 2006 (taken from the wave 2007).

Older workers are those aged 50 years or above. Younger workers are less than 50 years old.

$\left.{ }^{i}\right)$ Employees who predominantly work with a computer.

$\left.{ }^{i i}\right)$ IT intensity is an indicator comprising several IT variables. See section 3 for details.

Source: Author's calculations based on ZEW ICT survey 2004 and 2007. 
Table 7: Firm characteristics I of subsamples

\begin{tabular}{|c|c|c|c|c|}
\hline & \multicolumn{2}{|c|}{$\begin{array}{l}\text { IT-intensive } \\
\quad \text { firms }^{i}\end{array}$} & \multicolumn{2}{|c|}{$\begin{array}{c}\text { less IT-intensive } \\
\text { firms }^{i}\end{array}$} \\
\hline & prop. ${ }^{i i}$ & $\mathbf{N}$ & prop. ${ }^{i i}$ & $\mathbf{N}$ \\
\hline \multicolumn{5}{|l|}{ firm size (in groups) } \\
\hline less than 10 employees & .16 & 89 & .27 & 132 \\
\hline $10-49$ & .38 & 207 & .41 & 197 \\
\hline $50-249$ & .31 & 169 & .26 & 126 \\
\hline $250-499$ & .08 & 43 & .03 & 13 \\
\hline 500 or more employees & .08 & 44 & .03 & 15 \\
\hline firm age less than 7 years & .12 & 68 & .10 & 50 \\
\hline \multicolumn{5}{|l|}{ industry } \\
\hline consumer goods & .07 & 41 & .08 & 40 \\
\hline chemical industry & .05 & 25 & .06 & 31 \\
\hline other raw materials & .05 & 29 & .08 & 41 \\
\hline metal and machine construction & .09 & 50 & .15 & 73 \\
\hline electrical engineering & .07 & 37 & .06 & 29 \\
\hline precision instruments & .07 & 41 & .10 & 47 \\
\hline automobile manufacturing & .03 & 18 & .07 & 33 \\
\hline wholesale trade & .05 & 25 & .05 & 23 \\
\hline retail trade & .05 & 28 & .12 & 57 \\
\hline transportation and postal services & .05 & 29 & .09 & 44 \\
\hline banks and insurances & .08 & 42 & .02 & 11 \\
\hline electronic processing/telecommunication & .13 & 73 & .00 & 2 \\
\hline technical services & .12 & 67 & .04 & 19 \\
\hline other business-related services & .09 & 47 & .07 & 33 \\
\hline \multicolumn{5}{|l|}{ region } \\
\hline east & .19 & 105 & .29 & 139 \\
\hline west & .81 & 447 & .71 & 344 \\
\hline works council exists & .38 & 211 & .26 & 123 \\
\hline \multicolumn{5}{|l|}{ expected development of turnover ${ }^{i i i}$} \\
\hline decline & .19 & 106 & .25 & 120 \\
\hline constant & .37 & 205 & .44 & 211 \\
\hline increase & .44 & 241 & .31 & 152 \\
\hline firm provides training & .90 & 498 & .70 & 339 \\
\hline firm provides IT training & .78 & 429 & .43 & 207 \\
\hline firm provides IT training for older workers & .40 & 220 & .16 & 76 \\
\hline
\end{tabular}

Notes: Characteristics of firms included in the subsamples for analyzing the proportion (prop.) of older workers.

$\left.{ }^{i}\right)$ IT intensity is an indicator comprising several IT variables. IT-intensive firms are those firms with IT intensity greater than zero $(\mathrm{N}=552)$, less IT-intensive firms have an IT intensity of less than or equal to zero $(\mathrm{N}=483)$. See section 3 for details.

${ }^{i i}$ ) Percentage in sample.

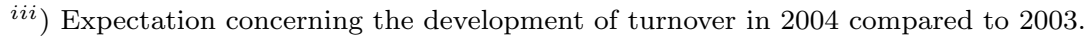

Source: Author's calculations based on ZEW ICT survey 2004. 
Table 8: Firm characteristics II - subsample: IT-intensive firms

\begin{tabular}{|c|c|c|c|c|c|}
\hline & Mean & Std. Dev. & Min & $\operatorname{Max}$ & $\mathbf{N}$ \\
\hline firm size & 177 & 531.34 & 1 & 8,000 & 552 \\
\hline prop. of older workers in 2006 & .17 & .15 & 0 & .83 & 552 \\
\hline prop. of workers with a university degree & .30 & .28 & 0 & 1 & 552 \\
\hline prop. of part-time workers & .11 & .14 & 0 & .95 & 552 \\
\hline prop. of workers using a computer ${ }^{i}$ & .65 & .31 & 0 & 1 & 552 \\
\hline prop. of workers receiving IT training & .18 & .24 & 0 & 1 & 552 \\
\hline prop. of older workers receiving IT training & .15 & .28 & 0 & 1 & 552 \\
\hline prop. of younger workers receiving IT training & .19 & .25 & 0 & 1 & 552 \\
\hline IT intensity ${ }^{i i}$ & .74 & .56 & 0 & 3.01 & 552 \\
\hline
\end{tabular}

Notes: Characteristics of subsample firms. All variables are taken from the wave of 2004, except the proportion (prop.) of older workers in 2006 (taken from the wave 2007).

Older workers are those aged 50 years or above. Younger workers are less than 50 years old.

$\left.{ }^{i}\right)$ Employees who predominantly work with a computer.

${ }^{i i}$ ) IT intensity is an indicator comprising several IT variables. IT-intensive firms are those firms with IT intensity greater than zero, less IT-intensive firms have an IT intensity of less than or equal to zero. See section 3 for details.

Source: Author's calculations based on ZEW ICT survey 2004 and 2007.

Table 9: Firm characteristics II - subsample: less IT-intensive firms

\begin{tabular}{|c|c|c|c|c|c|}
\hline & Mean & Std. Dev. & Min & Max & $\mathbf{N}$ \\
\hline firm size & 74 & 172.20 & 1 & 2,000 & 483 \\
\hline prop. of older workers in 2006 & .25 & .19 & 0 & 1 & 483 \\
\hline prop. of workers with a university degree & .12 & .19 & 0 & 1 & 483 \\
\hline prop. of part-time workers & .13 & .17 & 0 & 1 & 483 \\
\hline prop. of workers using a computer ${ }^{i}$ & .28 & .25 & 0 & 1 & 483 \\
\hline prop. of workers receiving IT training & .06 & .13 & 0 & 1 & 483 \\
\hline prop. of older workers receiving IT training & .04 & .14 & 0 & 1 & 483 \\
\hline prop. of younger workers receiving IT training & .07 & .15 & 0 & 1 & 483 \\
\hline IT intensity ${ }^{i i}$ & -.85 & .66 & -2.74 & 0 & 483 \\
\hline
\end{tabular}

Notes: See table 8.

Source: Author's calculations based on ZEW ICT survey 2004 and 2007. 


\section{References}

Acemoglu, D., and Pischke, J. (1999). The Structure of Wages and Investment in General Training. Journal of Political Economy, 107(3), 539-572.

Aubert, P., Caroli, E., and Roger, M. (2006). New Technologies, Organisation and Age: Firm-Level Evidence. The Economic Journal, 116(509), 73-93.

Bartel, A., and Sicherman, N. (1993). Technological Change and Retirement Decisions of Older Workers. Journal of Labor Economics, 11(1), 162-183.

Becker, G. (1962). Investment in Human Capital: A Theoretical Analysis. The Journal of Political Economy, 70(5), 9-49.

Beckmann, M. (2001). Die Auswirkungen des betrieblichen Personalabbaus auf die Altersstruktur der Belegschaften in westdeutschen Unternehmen. In U. Backes-Gellner, M. Kräkel, D. Sadowski, and J. Mure (Eds.), Entlohnung, Arbeitsorganisation und personalpolitische Regulierung (pp. 217242). Rainer Hampp Verlag, München/Mering, Germany.

Beckmann, M. (2007). Age-Biased Technological and Organizational Change: Firm-Level Evidence and Management Implications (discussion paper No. 05/07). Center of Business and Economics (WWZ).

Bellmann, L., and Ellguth, P. (2006). Verbreitung von Betriebsräten und ihr Einfluss auf die betriebliche Weiterbildung. In Jahrbücher für $N a$ tionalökonomie und Statistik (Vol. 226, pp. 487-504). Stuttgart, Germany.

Bellmann, L., and Leber, U. (2004). Ältere Arbeitnehmer und betriebliche Weiterbildung. In G. Schmid, M. Gangl, and P. Kupka (Eds.), Arbeitsmarktpolitik und Strukturwandel: Empirische Analysen, BeitrAB (Vol. 286, pp. 19-35). Nürnberg, Germany.

Bertschek, I. (2004). Führt IT-Nutzung zu altersfeindlicher Reorganisation von Arbeit? Eine Untersuchung auf Grundlage der IKT-Umfrage des ZEW. In B. Fitzenberger, W. Smolny, and P. Winker (Eds.), Herausforderungen an den Wirtschaftsstandort Deutschland, ZEW Wirtschaftsanalysen (Vol. 72, pp. 249-263). Nomos-Verlag, Baden-Baden, Germany.

Boockmann, B., and Zwick, T. (2004). Betriebliche Determinanten der Beschäftigung älterer Arbeitnehmer. Zeitschrift für Arbeitsmarktforschung, $37(1), 53-63$.

Bresnahan, T., Brynjolfsson, E., and Hitt, L. (2002). Information Technology, Workplace Organization and the Demand for Skilled Labor: Firm-Level Evidence. Quarterly Journal of Economics, 117(1), 339-376.

Büchel, F., and Pannenberg, M. (2004). Berufliche Weiterbildung in Ost- und Westdeutschland. Zeitschrift für Arbeitsmarktforschung, 37(2), 73-126. 
Burgert, D. (2006). Betriebliche Weiterbildung und der Verbleib Älterer im Betrieb (discussion paper No. 68). Research Institute on Professions (FFB).

Christensen, B. (2001). Berufliche Weiterbildung und Arbeitsmarktrisiko: Ein Matching-Ansatz (working paper No. 1033). Kiel Institute for the World Economy.

Clemens, W., Künemund, H., and Parey, M. (2003). Erwerbsbeteiligung und Arbeitsmarkt. In M. Herfurth, M. Kohli, and K. Zimmermann (Eds.), Arbeit in einer alternden Gesellschaft - Problembereiche und Entwicklungstendenzen der Erwerbsbeteiligung Älterer (pp. 43-64). Leske + Budrich, Opladen, Germany.

Eurostat. (2007). Information Society Statistics. http://epp.eurostat.ec.europa.eu. (accessed: February 15, 2008)

Fitzenberger, B., and Prey, H. (1999). Berufliche Weiterbildung und die Stabilität der Beschäftigung: Eine Evaluation auf der Basis des Sozio-Ökonomischen Panels. In D. Beer, B. Frick, R. Neubäumer, and W. Sesselmeier (Eds.), Die wirtschaftlichen Folgen von Aus- und Weiterbildung (pp. 139-164). Rainer Hampp Verlag, München/Mering, Germany.

Gerlach, K., and Jirjahn, U. (1998). Determinanten betrieblicher Weiterbildungsaktivitäten: Eine empirische Untersuchung mit Daten des Hannoveraner Firmenpanels. In F. Pfeiffer and W. Pohlmeier (Eds.), Qualifikation, Weiterbildung und Arbeitsmarkterfolg, ZEW Wirtschaftsanalysen (Vol. 31, pp. 311-337). Baden-Baden, Germany.

Hashimoto, M. (1981). Firm-Specific Human Capital as a Shared Investment. American Economic Review, 71(3), 475-482.

Hübler, O. (1998). Berufliche Weiterbildung und Umschulung in Ostdeutschland - Erfahrung und Perspektiven. In F. Pfeiffer and W. Pohlmeier (Eds.), Qualifikation, Weiterbildung und Arbeitsmarkterfolg, ZEW Wirtschaftsanalysen (Vol. 31, pp. 97-132). Baden-Baden, Germany.

Larwood, L., Ruben, K., Popoff, C., and Judson, D. (1997). Aging, Retirement, and Interest in Technological Retraining: Predicting Personal Investment and Withdrawal. The Journal of High Technology Management Research, $8(2), 277-300$.

Maddala, G. (1991). A Perspective on the Use of Limited-Dependent and Qualitative Variables Models in Accounting Research. The Accounting Review, 66(4), 788-807.

Pack, J., Buck, H., Kistler, E., Mendius, H., Morschhäuser, M., and Wolff, H. (1999). Zukunftsreport demographischer Wandel. Innovationsfähigkeit in einer alternden Gesellschaft.

http://www.demotrans.de/documents/Zukunft-dt.pdf. (accessed: March 03, 2008) 
Papke, L., and Wooldridge, J. (1996). Econometric Methods for Fractional Response Variables with an Application to 401(K) Plan Participation Rates. Journal of Applied Econometrics, 11(6), 619-632.

Stevens, M. (1996). Transferable Training and Poaching Externalities. In A. Booth and D. Snower (Eds.), Acquiring Skills: Market Failures, Their Symptoms, and Policy Responses (pp. 21-40). Cambridge, USA.

Tukey, J. (1949). One Degree of Freedom for Non-Additivity. Biometrics, 5, 232-242.

Wagner, J. (2001). A Note on the Firm Size - Export Relationship. Small Business Economics, 17(4), 229-237.

Wagner, P. (2000). Mit Älteren gegen Fachkräftemangel und Innovationsschwäche (IAB Materialien No. 4/2000). IAB.

Wooldridge, J. (2002). Econometric Analysis of Cross Section and Panel Data. MIT Press, Cambridge, USA.

Zwick, T. (2005). Continuing Vocational Training Forms and Establishment Productivity in Germany. German Economic Review, 6(2), 155-184. 